Chapter 2

\title{
Sustainability Aspects of In-Situ Bioremediation of Polluted Soil in Developing Countries and Remote Regions
}

\author{
Anders Jonsson and Henrik Haller \\ Additional information is available at the end of the chapter \\ http://dx.doi.org/10.5772/57315
}

\section{Introduction}

Xenobiotic and other toxic compounds from industrial activities are presently being accumulated in the ecosystems at an unsustainable rate. From an anthropocentric point of view such contamination is unsustainable because it threatens basic ecosystem functions and services that are necessary to maintain food security and provision of potable ground water. Furthermore natural habitats for plants and animals are threatened. Thousands of chemical compounds in varying concentrations and compositions have contaminated a wide range of habitats [1]. These contaminated sites demand diverse strategies and development of new technologies that are efficient and cheap enough to make remediation feasible even in remote areas and where financial support is limited.

Soil remediation has been a developing field for several decades and a common assumption is that it is a sustainable industry but very often clean-ups demand vast amounts of energy and lead to severe physical damage to the landscape. Traditional remediation technologies include soil excavation and landfill disposal. Sustainable remediation technology has been defined as a "remedy or combination of remedies whose net benefit on human health and the environment is maximized through the careful use of limited resources" [1]. Such technologies are only modestly implemented at present but new landfill legislations against "dig and dump" technologies can favour green solutions over chemical and energy-intensive techniques in the future [2].

Microorganisms have colonized some of the most extreme environments on the earth and some of them are efficient degraders of the pollutants that our industrial society produces. Bioremediation is a technology that uses living organisms and their enzymes to degrade, remove 
or immobilize toxic compounds [3]. Bioremediation have been gaining terrain recently [1] and some authors predict a further increase as technological advances surmount the limitations that exist today.

In this chapter we briefly discuss how principles of ecological engineering in concurrence with the application of basic thermodynamic principles and kinetic modelling can provide useful tools for the development of energy conserving and economically feasible bioremediation projects. We further discuss the potential of organic waste materials and by-products in locally adapted soil bioremediation. Finally we present some illustrative cases of novel research on sustainable bioremediation for tropical developing countries and remote locations and discuss some promising fields of future research and possible future applications.

\section{Bioremediation and ecological engineering}

Ecological engineering has been proposed as a theoretical framework to design "sustainable ecosystems that integrate human society with its natural environment for the benefit of both" [4]. Bioremediation is generally considered an ecological engineering practice but even if it addresses one of the core goals of ecological engineering, i.e. restoration of damaged ecosystems [5], bioremediation can be energy-intensive and have a serious impact on the remediated ecosystems particularly if excavation and ex situ methods are employed.

Mitsch and Jørgensen [5] identify 5 basic concepts that have been developed to distinguish ecological engineering from other approaches such as industrial ecology, biotechnology or environmental engineering. Ecological engineering:

1. is based on the self-designing capacity of ecosystems

2. can be the acid test of ecological theories

3. relies on systems approaches

4. conserves non-renewable energy sources

5. supports ecosystem conservation

If used collectively, these 5 concepts can provide guidelines for design of sustainable bioremediation projects. In a sustainable society the ultimate goal is to limit the rate of pollution to what ecosystems can assimilate and break down without long term negative effects on ecosystem functions or human health. Meanwhile that goal is attained we will have to give the ecosystems a hand to boost their intrinsic biodegradation capacity.

\subsection{Self design}

Self-design is the property of a system to reorganise in an unstable non-homogeneous environment [5]. The inclusion of self design in a project can facilitate the implementation of flexible strategies that adapt to new conditions. The powerful capacity of ecosystems to reorganise after change can be used in bioremediation projects as a means to reduce costs and 
energy use. Consortiums of soil microorganisms naturally restructure to adapt to new conditions including contamination and are therefore good candidates for self-design strategies. A typical microbial community in soil consist of less than $1 \%$ hydrocarbon degraders but that fraction can increase to $10 \%$ after exposure to oil pollutants [6]. An example of how engineers can accelerate the ecosystems self-designing capacity is the introduction of a microbial strain with capacity to initiate degradation of high molecular-weight pollutants that later provide food (energy) for other microorganisms that take care of the metabolic byproducts as the introduced strain dies off. In conventional engineering, items are often designed to behave in an as predictable way as possible since reliability and robustness are desired criteria of safety and quality. The outcomes of a technology that depend on self-design, on the contrary, are often a lot more difficult to predict. Bioremediation projects that include self-designing strategies thus require thorough monitoring to make sure that the degradation of the pollutants is satisfactory.

\subsection{The acid test}

Just as strong acids were traditionally used to distinguish gold from base metals, a full scale bioremediation project can be used to confirm or reject ecological theories. Ecological theories provide a useful framework that establishes restrictions and opportunities for bioremediation strategies. The complex nature of full scale in-situ bioremediation however might lead to outcomes somewhat different from what was expected. Since intense use of monitoring is required for full scale implementations of unproven technologies, the result from these can be used to refine the theories on which the project was based.

\subsection{A systems approach}

Reductionist analysis of the parts of a system in isolation from each other can provide important data and basic understanding of significant mechanisms but should be combined with a holistic view of the entire system in order to achieve a sustainable bioremediation project. The site specific conditions of the ecosystem that is subject to remediation must be quantified and analysed with appropriate models. That particular ecosystem however is part of a greater context whose characteristics must also be born in mind. When bioremediation strategies are chosen, socioeconomic and even cultural aspects must be taken into account. Questions like "what is the economic impact of the project?", "can polluted land be reclaimed for food production or construction?", "what resources are available in the human environment around the site?" might supply useful information. The use of locally available agricultural waste products, that are potential polluters by themselves, as amendments (see section about waste recycling) is an example of advantageous design that requires a systems approach. The source of the pollution must also be addressed to make sure that the remediation project isn't an encouragement to further pollution.

\subsection{Non-renewable resources conservation}

Energy use is one of the major sustainability issues for conventional remediation projects. Exsitu remediation is typically too energy-intensive to be considered ecological engineering. 
Furthermore it resembles what Jørgensen \& Mitsch [5] call a shell game, in which pollutants are moved from one location to another. In sustainable bioremediation external energy input is ideally used only in the initiation phase to start a process that is subsequently powered by solar energy and the embodied chemical energy of the pollutant itself. The engineer's role is to facilitate the proper conditions in which such a process can take place.

\subsection{Ecosystem conservation}

The ability to cycle nutrients is a fundamental function of all ecosystems. Within the mattercycling function lies the catabolic capacity to degrade and mineralise molecules of varying complexity, including pollutants. This function alone gives a nonmarket value to ecosystems, not always recognised by society. The role of ecological engineers is to identify ecosystem functions that are adoptable to human needs and apply them in ways that doesn't create any further degradation of nature. Since bioremediation projects aims at eliminating pollution that exerts stress on the ecosystem, it is by definition an ecosystem conservation approach. However, if large amounts of soil are physically removed from the site in ex-situ operations the remediation itself might be a threat to the ecosystem. Bioremediation projects are typically involved in the restoration of disturbed ecosystems but measures to prevent toxic compounds from entering sound ecosystems are likewise part of the bioremediation agenda.

\section{Thermodynamic and kinetic considerations on bioremediation}

The fact that most organic pollutants are composed of molecules with high embodied energies is an interesting starting point for any consideration about the best practice for sustainable soil remediation, especially in remote locations and developing countries where energy-intensive project are cost-prohibitive. Economic incentives are generally small for any kind of remediation practice in such regions and, furthermore, time constraints may not be as limiting as in highly developed urban environments. Technologies that manage to optimize the use of ecosystem services provided by indigenous organisms, in combination with a minimum input of extra energy and material resources, are potentially more sustainable in such conditions.

Figure 1 illustrates some basic principles including thermodynamic driving forces (from molecules with high to low embodied energy) and available transformation pathways in air and soil. In the atmosphere, abiotic photochemical reactions rapidly oxidize organic vapours. The rate determining step in these complex photochemical reactions is usually the initial attack on the primary pollutant by hydroxyl radical. Typical turnover times of i.e. reactive hydrocarbons are only a few hours in the sunlit atmosphere while lack of photochemistry in the subsurface of soils leads to significantly lower reaction rates and hence to much longer turnover times of pollutants.

In soils where conditions for microbial activity are unfavourable, degradation relies on abiotic chemical reactions. In such cases organic pollutants may persist for years to decades or longer and secondary, incompletely degraded products may accumulate. On the other hand if conditions are favourable (temperature, electron acceptors, nutrients, moisture, available 


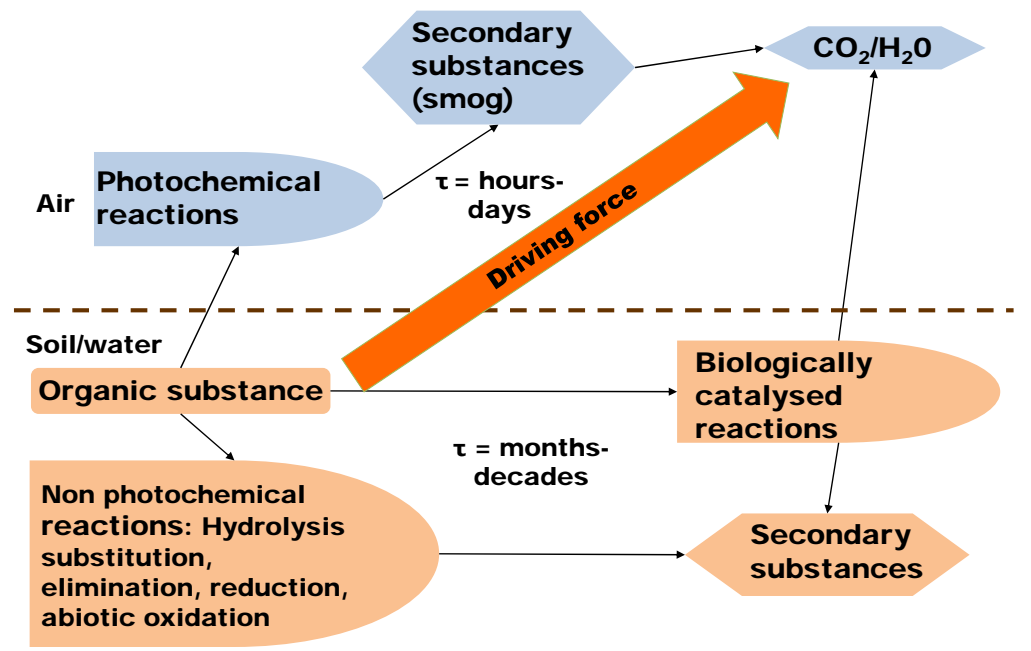

Figure 1. Chemical and biochemical transformations and mineralisation of organic substances in polluted soil and in air. The broad arrow indicates the thermodynamic driving force for the complete degradation of the pollutant in an oxidising environment. Typical average residence times of organic pollutants $(\tau)$ in air and soil are indicated.

carbon sources, low toxicity to microorganisms, $\mathrm{pH}$, to mention some of the most determinant variables), microorganisms such as bacteria and fungi may use the organic pollutant as a source of energy and carbon. Enzymatic degradation is generally much faster than abiotic oxidation reactions and the organic pollutant that enters the metabolic pathways of soil microorganisms may be partly or completely mineralized. The driving force for such an enzymatic process is again the free energy potential that can be used by the organism. For typical hydrocarbon and oxygenate pollutants the free energy that is available by complete oxidation with oxygen as electron acceptor, is in the range of $3-12 \times 10^{3} \mathrm{KJ} \mathrm{mol}^{-1}$ or $37-46 \mathrm{MJ} \mathrm{kg}^{-1}$, as can be seen in table 1. This energy potential may be used by a wide range of heterotrophic microorganisms.

In areas of hydrocarbon contamination the most commonly found heterotrophic bacteria are of the genera Pseudomonas, Achromobacter, Arthrobacter, Micrococcus, Vibrio, Acinetobacter, Brevibacterium, Corynebacterium, Flavobacterium, Mycobacterium and Nocardia [7]. Some soil microorganisms that are incapable of utilizing the full embodied energy potential of the pollutant may still be able to initiate catabolic processes that ultimately lead to complete mineralisation if oxygen is present at sufficient concentration. Filamentous fungi, such as e.g., white-rot fungi, can oxidize recalcitrant high molecular weight polycyclic aromatic hydrocarbons (PAH:s) with their extracellular enzymes to more water soluble substances. Both lignolytic and non lignolytic fungi has been shown to initiate degradation of high molecularweight $\mathrm{PAH}$ and the oxidation products formed are thereby made available for further degradation by bacteria [8]. Such interactions between soil microorganisms is an important factor to consider in sustainable soil bioremediation and remediation practices that favour a high soil microbial biodiversity are likely to be more sustainable. 


\begin{tabular}{|c|c|c|c|c|c|c|c|c|c|c|c|c|}
\hline \multirow[t]{2}{*}{ Category } & \multirow[t]{2}{*}{ Substance } & \multirow[t]{2}{*}{ Formula } & \multirow[t]{2}{*}{ Phase } & \multirow{2}{*}{$\begin{array}{c}\mathrm{M} \\
\mathrm{g} \mathrm{mol}^{-1}\end{array}$} & $\mathrm{~S}^{\circ}$ & $\Delta H^{\circ}{ }_{f}$ & $\Delta \mathrm{S}^{\circ}{ }_{\mathrm{f}}$ & \multirow[t]{2}{*}{$\Delta \mathbf{G}^{\circ}{ }_{\mathrm{f}}$} & \multirow[t]{2}{*}{ b } & \multirow[t]{2}{*}{ c } & \multicolumn{2}{|c|}{$\begin{array}{l}\Delta \mathrm{G}^{\circ}(\text { minerali- } \\
\text { sation })\end{array}$} \\
\hline & & & & & $\mathrm{J} \mathrm{mol}^{-1} \mathrm{~K}^{-1}$ & $\mathrm{KJ} \mathrm{mol}^{-1}$ & $\mathrm{KJ} \mathrm{mol}^{-1}$ & & & & $\mathrm{KJ} \mathrm{mol}^{-1}$ & MJ kg-1 \\
\hline Gasoline & Benzene & $\mathrm{C}_{6} \mathrm{H}_{6}$ & Liquid & 78.11 & $173.26^{\#}$ & $49.0^{\#}$ & -253.78 & 124.66 & 6 & 3 & -3202 & -41.00 \\
\hline Gasoline & Toluene & $\mathrm{C}_{7} \mathrm{H}_{8}$ & Liquid & 92.14 & $220.96^{\#}$ & $12.0^{\#}$ & -342.59 & 114.14 & 7 & 4 & -3823 & -41.50 \\
\hline Gasoline & m-xylene & $\mathrm{C}_{8} \mathrm{H}_{10}$ & Liquid & 106.16 & $253.80^{\#}$ & $-25.4^{\#}$ & -446.26 & 107.65 & 8 & 5 & -4448 & -41.90 \\
\hline $\begin{array}{l}\text { Gasoline } \\
\text { additive }\end{array}$ & MTBE & $\mathrm{C}_{5} \mathrm{H}_{12} \mathrm{O}$ & Liquid & 88.15 & $265.3^{\#}$ & $-315.4^{\#}$ & -650.52 & -121.45 & 5 & 6 & -3273 & -37.14 \\
\hline Diesel & Hexadecane & $\mathrm{C}_{16} \mathrm{H}_{34}$ & Liquid & 226.44 & $586.18^{\#}$ & $-456.3^{\#}$ & -1728.71 & 59.11 & 16 & 17 & -10401 & -45.93 \\
\hline Diesel & Octadecane & $\mathrm{C}_{18} \mathrm{H}_{38}$ & Solid & 254.49 & $480.2^{\#}$ & $-457.4^{\#}$ & -2107.71 & 171.01 & 18 & 19 & -11776 & -46.27 \\
\hline Diesel & Phenanthrene & $\mathrm{C}_{14} \mathrm{H}_{10}$ & Solid & 178.23 & $215.06^{\#}$ & $110.1^{\#}$ & -520.00 & 265.14 & 14 & 5 & -6972 & -39.12 \\
\hline Diesel & Perylene & $\mathrm{C}_{20} \mathrm{H}_{12}$ & Solid & 252.31 & $264.6^{\#}$ & $182.4^{\#}$ & -636.14 & 372.07 & 20 & 6 & -9682 & -38.37 \\
\hline $\begin{array}{l}\text { Mineralisation } \\
\text { product }\end{array}$ & $\begin{array}{l}\text { Carbon } \\
\text { dioxide }\end{array}$ & $\mathrm{CO}_{2}$ & Gas & 44.01 & $213.79^{\#}$ & $-393.5^{\#}$ & 2.81 & -394.36 & & & & \\
\hline $\begin{array}{l}\text { Mineralisation } \\
\text { product }\end{array}$ & Water & $\mathrm{H}_{2} \mathrm{O}$ & Liquid & 18.02 & $69.95^{\#}$ & $-285.8^{\#}$ & -163.30 & -237.19 & & & & \\
\hline Element & Carbon & C & $\begin{array}{l}\text { Solid } \\
\text { (graphite) }\end{array}$ & 12.01 & $5.83^{\#}$ & 0 & 0 & 0 & & & & \\
\hline Element & Hydrogen & $\mathrm{H}_{2}$ & Gas & 2.02 & $130.68^{\#}$ & 0 & 0 & 0 & & & & \\
\hline Element & Oxygen & $\mathrm{O}_{2}$ & Gas & 32.00 & $205.15^{\#}$ & 0 & 0 & 0 & & & & \\
\hline
\end{tabular}

\#NIST, National Institute of Standards and Technology website. Available at: http://webbook.nist.gov/chemistry/nameser.html

Table 1. Thermodynamic properties and free energy of mineralisation of some representative "high energy" organic substances commonly found in polluted soil. Standard entropy of formation $\left(\Delta \mathrm{S}_{\mathrm{f}}^{\circ}\right)$ was calculated from standard entropy values $\left(\mathrm{S}^{\circ}\right)$ of the substances and their elements (phase indicated in table). Standard free energy of formation $\left(\Delta \mathrm{G}_{\mathrm{f}}^{\circ}\right.$ was calculated from standard enthalpy of formation $\left(\Delta \mathrm{H}_{\mathrm{f}}^{\circ}\right)$ and standard entropy of formation. Standard free energy of mineralisation $\left(\Delta \mathrm{G}^{\circ}\right)$ was calculated for the complete oxidative degradation of the organic compounds to the thermodynamically most stable end products according to the reaction: 1 mol of substance $+a \mathrm{O}_{2}=\mathrm{b} \mathrm{CO}_{2}+\mathrm{c} \mathrm{H}_{2} \mathrm{O}$.

In oxygen depleted soils microorganisms are unable to mineralise organic compounds to inorganic molecules only. Complete degradation leaves carbon dioxide and methane as end products. Intermediate fermentation products, that may be toxic to microorganisms and plants, may accumulate if they are not converted to methane [7]. Since methane and fermentation products has retained a substantial part of the embodied energy, the energy gain by microorganisms by anaerobic degradation is less than under aerobic conditions and the thermodynamic driving force for biodegradation is thus lower. Methane is also a highly potent greenhouse gas [9] and its unintended production should, from a sustainability point of view, be avoided. It is therefore in many cases preferable to maintain aerobic conditions in the soil during in-situ bioremediation projects. There are however some important exceptions. Xenobiotic and toxic chlorinated organic compounds such as e.g. highly chlorinated PCB:s, pentachlorophenol, tri- and perchloroethylene, gamma hexachlorocyclohexane (lindane) and many others are highly persistent to biodegradation under aerobic conditions. The reason for 
this may be lack of metabolic pathways available to common soil microorganisms that can generate energy gain for the organism. Persistence is also caused by high lipophilicity of many of these substances which reduce their bioavailability.

Chlorinated substances may be efficiently degraded by microorganisms capable of halorespiration under anaerobic conditions [10]. The degradation mechanism is characterized as reductive dechlorination. In contrast to aerobic co-metabolism which does not provide any energetic benefit for the degrading organism, reductive dechlorination may provide a substantial free energy yield. The thermodynamic driving force of such reactions is demonstrated by the fact that hexachloroethane for example, may be a stronger electron acceptor than oxygen [11].

\subsection{Kinetic considerations}

Biodegradation kinetics tells us not only about the rate of degradation of target compounds and of rate dependence on ambient factors, but by studying the shape of the degradation curves we may also get valuable information about degradation mechanisms. It is preferable to use models that have a theoretical basis rather than just empirical mathematical modelling that have limited predictive ability.

Natural attenuation of organic pollutants are typically mediated by slow growing organisms and if the concentration of pollutants is much lower than the concentration required for maximum growth of degrading organism (which is often the case in many polluted soils) then first order kinetics may apply, i.e. degradation rate is directly dependent on substrate concentration (Equation 1).

$$
-\mathrm{dC} / \mathrm{dt}=\mathrm{kC}
$$

$\mathrm{C}$ is the substrate concentration and $\mathrm{k}$ is the first order rate constant. First order kinetics is often applied in degradation studies because of its simplicity but have little predictive power when conditions for growth change.

In situations with rapid growth of degrading organisms or when other factors than the substrate concentration controls the rate of degradation, first order kinetics will not describe the degradation process accurately. According to the earlier mentioned criteria for sustainable soil bioremediation, efforts should be made to stimulate growth of indigenous soil microorganisms that have or can achieve the ability to degrade target pollutants. The addition of organic waste products from the dairy industry that promotes growth of degrading organisms has been proved to be an efficient means to increase both rate and total degradation of some representative diesel range hydrocarbons in soil [12-14]. Although the addition of readily available carbon sources, such as lactose, lactate and amino acids (components of whey) to contaminated soil would be expected to trigger exponential growth of organisms, a common phenomenon in liquid culture media, it seems that the soil matrix itself does not readily promote exponential growth of degrading organisms. Growth of soil microorganisms is limited by a number of factors caused by the properties of the soil matrix. Among the limiting 
factors is diffusion of substrate and nutrients but also the specific area available for bacterial sorption on to soil particles. When a large fraction of this area is occupied by bacteria, further growth might be increasingly restricted by diffusion of substrate and nutrients into multilayers of bacteria. Kinetic models that take into consideration slow or restricted (linear growth) may more accurately describe degradation patterns in real life situations. Figure 2 illustrates the application of a three-half-order kinetic model (II) originally proposed by Brunner and Focht [15]. The model assumes linear biomass growth rate and simulates the accumulated ${ }^{14} \mathrm{CO}_{2}$ production from phenanthrene-9- ${ }^{14} \mathrm{C}$ mineralisation in soil microcosms.

$$
P(t)=S_{0}\left(1-\exp \left(-k_{1} t-k_{2} t^{2} / 2\right)\right)+k_{0} t
$$

$\mathrm{P}[\mathrm{t}]$ is the cumulative ${ }^{14} \mathrm{CO}_{2}$-production (\%) where $\mathrm{t}$ is the time (days), $\mathrm{S}_{0}$ is the amount of substrate (\%) that is "highly bioavailable", $\mathrm{k}_{1}$ is the first-order rate constant (day ${ }^{-1)}, \mathrm{k}_{2}$ is a linear growth term $\left(\right.$ day $^{-2)}$, and $k_{0}$ is the zero order rate constant describing the mineralisation of "less bioavailable" substrate and indigenous mineralisation $\left(\%\right.$ day $\left.^{-1}\right)$. The lag time was defined as the initial time until $1 \%$ of the added ${ }^{14} \mathrm{C}$ was detected as ${ }^{14} \mathrm{CO}_{2}$ [16]. From the end of the lag phase, iterative non-linear least squares regression was performed to fit data to the model by using the SOLVER function in Microsoft Excel 2000 [17].

The effects of applications of different amendments on phenanthrene biodegradation are clearly seen in figure 2 . Kinetic parameters such as the linear growth term $\left(\mathrm{k}_{2}\right)$ and $\mathrm{S}_{0}$ was significantly affected by the addition of the different amendments (Table 2). It should be noted that the stimulating effect of complex organic amendments such as whey and fermented whey may not only be an effect of the addition of a readily available carbon source (that promotes growth) but also of available micronutrients, such as B-vitamins, that is required to maintain efficient catabolic pathways for degradation of i.e. polycyclic aromatic hydrocarbons.

\begin{tabular}{|c|c|c|c|c|c|c|c|}
\hline & $\begin{array}{l}\text { Lag time } \\
\text { (days) }\end{array}$ & $\begin{array}{l}S_{0} \\
(\%)\end{array}$ & $\begin{array}{c}k_{1} \\
\left(\text { day }^{-1}\right)\end{array}$ & $\begin{array}{c}\mathbf{k}_{2} \\
\left(\text { day }^{-2}\right)\end{array}$ & $\begin{array}{c}\mathbf{k}_{0} \\
\left(\% \text { day }^{-1}\right)\end{array}$ & $\mathbf{R}$ & $\begin{array}{c}\text { Mineralisation } \\
\text { after } 391 \text { days } \\
\text { (\%) }\end{array}$ \\
\hline Control & 21 & $51.3^{\mathrm{a}}$ & 0 & $4.35^{\mathrm{a}} \times 10^{-5}$ & 0 & 0.973 & $46.3^{\mathrm{ab}}$ \\
\hline FW low & 24 & $53.8^{a}$ & 0 & $5.83^{b} \times 10^{-5}$ & 0 & 0.997 & $52.1^{a}$ \\
\hline FW high & 87 & - & - & - & - & - & $14.4^{c}$ \\
\hline SW low & 21 & $48.6^{a}$ & 0 & $4.09^{a} \times 10^{-5}$ & 0 & 0.974 & $43.4^{b}$ \\
\hline SW high & 18 & $63.2^{\mathrm{b}}$ & 0 & $20.8^{c} \times 10^{-5}$ & $0.0046^{a}$ & 0.983 & $66.3^{d}$ \\
\hline FW multi & 15 & $65.0^{\mathrm{b}}$ & 0 & $63.6^{d} \times 10^{-5}$ & $0.014^{a}$ & 0.992 & $70.8^{e}$ \\
\hline
\end{tabular}

Table 2. Tree-half-order kinetic constants for phenanthrene mineralisation in soil, at $25^{\circ} \mathrm{C}$. Lag time is expressed in units of days, $\mathrm{S}_{0}$ and mineralisation in $\%, \mathrm{k}_{1}$ in day ${ }^{-1}, \mathrm{k}_{2}$ in day ${ }^{-2}, \mathrm{k}_{0}$ in $\%$ day ${ }^{-1}$ and $\mathrm{R}$ is the correlation coefficient. Values having the same superscript letters are not significantly different at a $95 \%$ level. (From [18]. Reprinted with permission from Elsevier). 


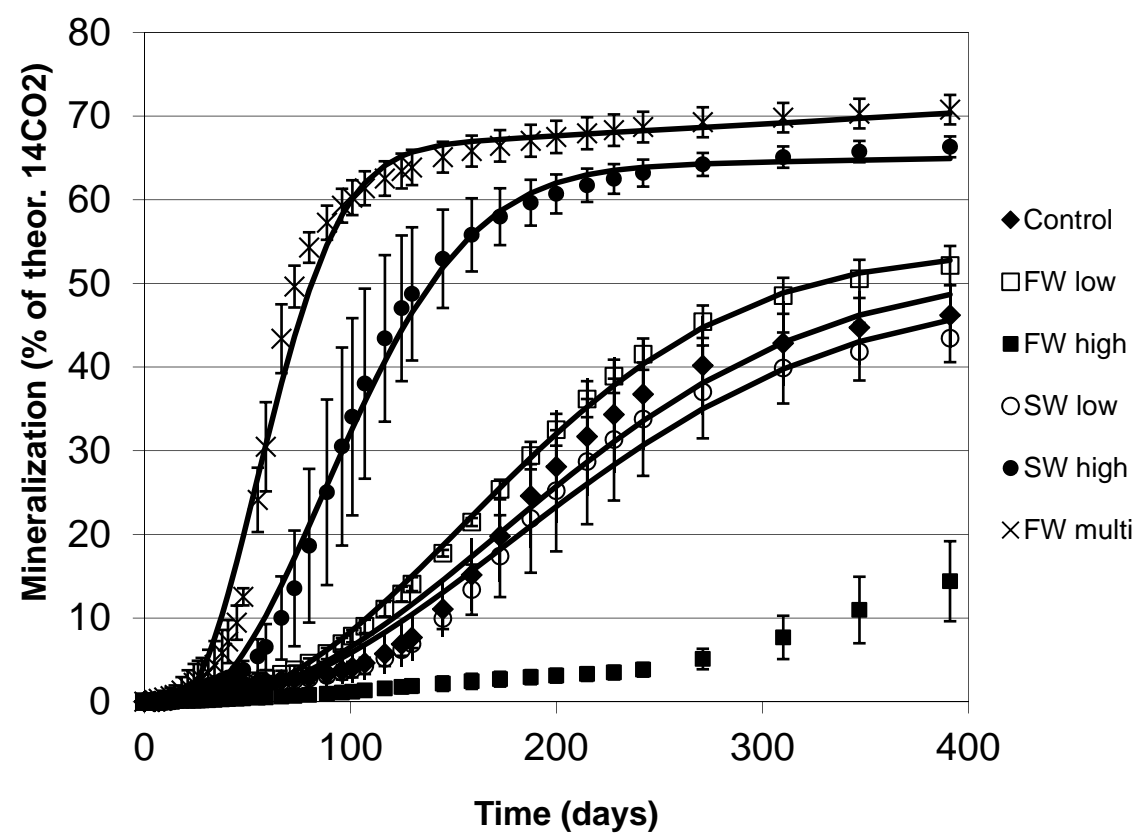

Figure 2. Effect of added fermented whey and sweet whey on ${ }^{14} \mathrm{C}$-phenanthrene mineralisation to ${ }^{14} \mathrm{CO}_{2}$ in soil at 25 ${ }^{\circ} \mathrm{C}$. FW low = Fermented whey $210 \mathrm{mg} \mathrm{dw} \mathrm{kg}^{-1}$ soil dw; FW high = Fermented whey $2100 \mathrm{mg} \mathrm{dw} \mathrm{kg}^{-1}$ soil dw; SW low = Sweet whey $210 \mathrm{mg} \mathrm{dw} \mathrm{kg}^{-1}$ soil dw; SW high = Sweet whey $2100 \mathrm{mg} \mathrm{dw} \mathrm{kg}^{-1}$ soil dw, all added at the beginning of the experiment. FW multi = Fermented whey $210 \mathrm{mg} \mathrm{dw} \mathrm{kg}^{-1}$ soil dw added at the beginning of the experiment and then every $14^{\text {th }}$ day. The curves are fitted to the data by use of the three-half-order kinetic model. Kinetic parameters are given in table 2 (From [18]. Reprinted with permission from Elsevier).

\section{Waste recycling}

Organic by-products are produced globally on a massive scale. Economic operations such as agriculture, livestock, fishing and forestry [19-21] generate a number of by-products that can be seen in Figure 3. Frequently unexploited organic waste products create serious environmental problems when disposed of [20]. Agriculture is the economic base of most tropical developing countries, accounting for $50 \%$ of the employment [21]. Organic by-products from agriculture, forestry, fishery and livestock operations are thus available in abundance and are typically of limited economical value [19]. Animal feed has been proposed as an outlet for some of these by-products but due to low levels of protein, high levels of moisture and some antinutritional factors i.e. presence of tannins and polyphenols, this practice is limited [22]. However, being inexpensive and easily available sources of carbon, nutrients and bioactive compounds, many of these by-products can potentially be used as sources of readily available carbon for bioremediation purposes [23]. 


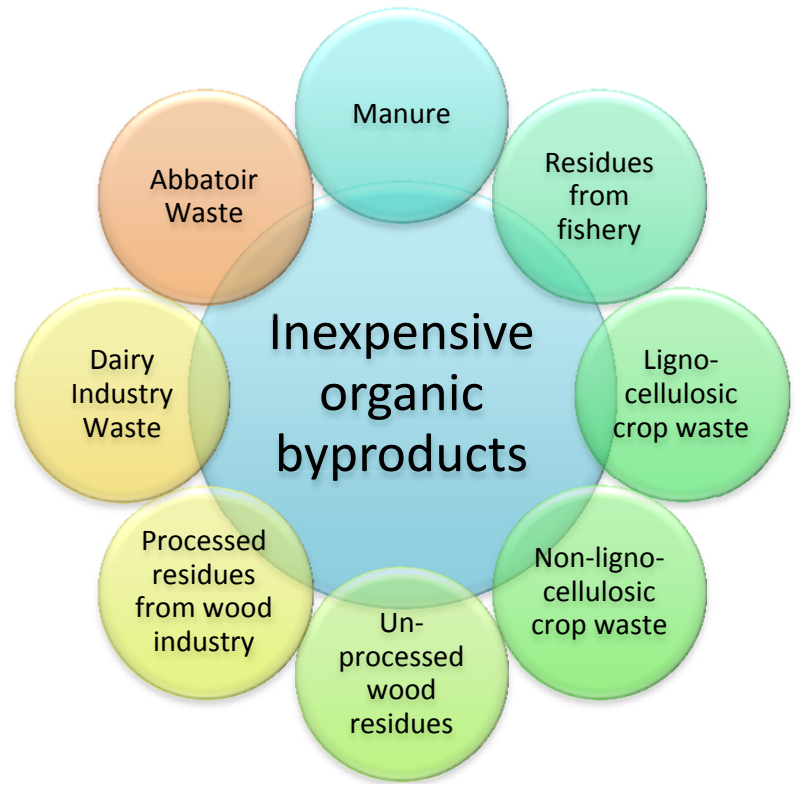

Figure 3. Some organic by-products that potentially can be used as amendments for bioremediation.

A number of organic by-products have the ability to enhance the degradation of different toxic compounds including lignocellulosic wastes such as sugarcane, bagasse and sawdust [26], crop residues such as coffee pulp [27] and molasses [28] and whey, a by-product of the dairy industry [12-14]. Three examples of inexpensive by-products with potential or confirmed bioremediation capacity are described in more detail below: pyroligneous acid, compost teas and whey.

\subsection{Pyroligneous acid}

Pyroligneous acid (PA) is a by-product of charcoal production [29] with a limited economic value that is also referred to as wood vinegar, pyrolysis oil, smoke extract, bio-oil etc. [30, 31]. PA is typically disposed of as waste [31] but in Japan it has been used for centuries to increase crop production and to combat agricultural pests [29, 32]. At present, the majority of the charcoal consumed worldwide is produced in traditional kilns in developing countries [33]. Such charcoal production lacks appropriate control of the gas and vapours produced in the process and causes land and air pollution [34]. Production systems exist however that recover these condensate co-products or use them as fuel in the pyrolysis process, reducing the emission to a minimum [30]. Several low tech kilns that recover the PA from the charcoal production have been developed including the advanced Brazilian beehive kiln and the Casamance kiln [35]. In recent years the research and technology concerning PA have advanced significantly [30], and the current trend in charcoal production is to improve the environmental performance while maintaining or improving charcoal yield and quality. The chemical 
composition of PA varies depending on factors such as type of feedstock, pyrolysis temperature and duration etc. [25, 30]. The most frequently identified compounds in PA include methanol, acetic acid, methyl acetone, acetaldehyde, furan, furfural and volatile organic acids. PA contains phenolic compounds that are known to have antimicrobial properties [36] and PA has successfully been used to control fungal growth on wood [30] and bacterial decay of foods $[36,37]$. At low concentrations however, PA has been shown to stimulate germination, growth and yield in a wide range of plants [37]. Although the growth promoting effect of PA is not yet clearly understood it has been attributed to nutritious components such as nitrates of $\mathrm{Ca}$, $\mathrm{Mg}, \mathrm{K}$, magnesium sulphate etc. but also to its stimulatory effect on symbiotic fungi and bacteria [31]. The formation of fruit bodies of hydrocarbon-degrading fungi such as Lentinus edodes and Pleurotus ostreatus was significantly increased after applications of PA to the growth medium [38]. Furthermore PA has been shown to significantly increase basal respiration and microbial biomass in highly weathered tropical soils suggesting that microbes used PA for their metabolism [29].

\subsection{Compost teas}

Compost teas (CT) are liquid compost extracts obtained when compost is soaked in water for a determined number of days. Optionally additives (derived from by-products) such as molasses, fish hydrolysate, rock dust, yeast extract, humic acids etc. are used to add nutrients and stimulate microbial activity. To date virtually all research on CT has focused on its potential to control plant diseases in agriculture. However, the fact that CT have proved to significantly increase soil microbial respiration and dehydrogenase activity [39] makes it an interesting candidate for bioremediation. A number of production parameters (e.g. aeration, compost source, nutrient additives etc.) have been manipulated in order to optimize plant disease suppression [40]. To date, consensus on optimum production parameters for disease suppression hasn't been reached and some studies report inconsistency in the performance [41]. However a number of reports have shown that aeration and additions of nutrients lead to significant increases of the cell mass of active bacteria [39, 40,42] and the addition of humic acids and yeast extracts significantly increased the fungal populations [43]. Plate counts and microscopic examination studies have revealed that aerated CT has bacterial population dominated by Bacillus sp., Lactobacillus sp., Micrococcus lutues, Staphylococcus sciuri, Pseudomonas putida, Burkholderia glumae and Clavibacter agropyri while species of Aspergillus, Penicillium and Trichoderma dominated the fungal communities [43]. Many of these organisms have the capacity to degrade a number of toxic substances including PAH:s and organochlorine compounds [44, 45].

In a recent study, applications of compost teas made from vermicompost caused significantly greater dehydrogenase activity and microbial respiration [39] which makes it an interesting candidate for bioremediation. Vermicompost generally has higher concentrations of available nutrients $\left(\mathrm{NO}_{3}{ }^{-}\right.$, exchangeable $\mathrm{Ca}, \mathrm{P}$ and soluble $\left.\mathrm{K}\right)$ and significantly larger and more diverse microbial populations than common compost. Microorganisms found in worm castings of Eisenina fetida have caused increased catabolic activity and enhanced degradation of PAHs in a number of experiments $[46,47]$. 


\subsection{Whey}

Whey is produced when milk casein is removed from the milk in dairy operations to make cheese and other products. This liquid by-product constitutes between $85-95 \%$ of the milk volume and $55 \%$ of milk nutrients remain in the whey. About half of the yearly global production of 145 million tonnes is utilized for animal feed etc. The remaining large volumes end up as potential contaminants in the environment [48]. The chemical content of whey is characterised by lactose, a number of essential and non-essential amino acidsin different proportions, vitamin B1,2,6,7,12, folic acid and lactic acid [12,13]. Relatively few studies have been performed on the effect of whey on biodegradation of organic pollutants [12]. However, research at Mid Sweden University has showed that the degradation of aliphatic and aromatic hydrocarbons can be significantly enhanced by the addition of whey and fermented whey [12, 13]. The biodegradationenhancing effect of whey was primarily attributed to an increased microbial biomass stimulated by the readily available carbon source [12]. The degradation studies also showed a more complex dependence of carbon sources and growth factors, such as B-vitamins, on the degradation of an aromatic compound (phenanthrene) compared to an aliphatic compound (hexadecane) [18]. These results indicate that the presence of co-factors such as vitamins and micronutrients may beimportant to consider when evaluating the suitability of organic amendments for bioremediation of soil contaminated by various types of organic pollutants.

\section{Case studies}

Different technologies and strategies are necessary to remediate the present and future soil pollution. As our understanding of the degradation mechanisms of different pollutants evolves, so do our chances to develop alternative and complementary strategies that can take the concentrations of toxic compounds to a sustainable level. Since 2006, a research group at Mid Sweden University has undertaken research dedicated to the development of bioremediation methods for low priority remediation sites including, remote locations and tropical developing countries. Ecological engineering provide an appealing theoretical framework in such locations where energy and material costs are limiting factors. The research has implied laboratory experiments as well as pilotscaleand in-situ projectsin tropical and temperateclimate. It includes pilot scale experiments in an experimental station that was developed in Nicaragua (se figure 4) and field trials in remote parts of northern Sweden where transport distances are long and the cold climate constitutes an additional challenge to in-situ bioremediation projects.

\subsection{Field station in Nicaragua, designed for bioremediation experiments in a tropical climate}

Waste management programs in developing countries are often deficient and the inappropriate disposal of hazardous waste creates pollution problems. Furthermore the use of pesticides and other toxic products is minimally restricted in many developing countries which leads to extensive contamination with persistent substances such as polycyclic aromatic hydrocarbons and organochlorine pesticides $[49,50]$. The experimental station in Nicaragua (figure 5) is 

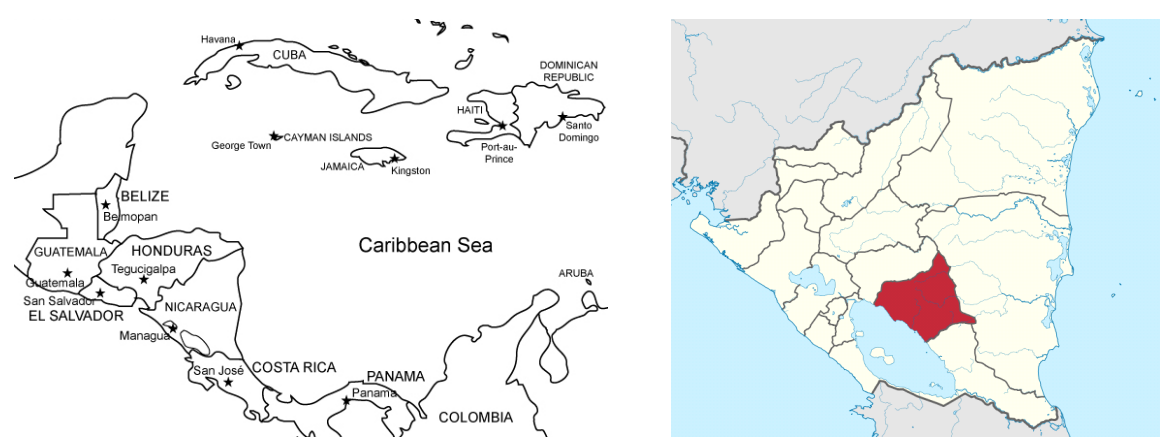

Figure 4. Left picture: Map of Central America and Nicaragua. Right picture: The red marked area is Chontales, the region where Mid Sweden University's pilot scale experimental station is located. (Map of Central America by Виктор B licensed under Creative Commons Attribution-Share Alike 2.0 Generic, Mapa de Nicaragua mostrando al departamento de Chontales by Vrysxy licensed under Creative Commons Attribution-Share Alike 3.0 Unported.)

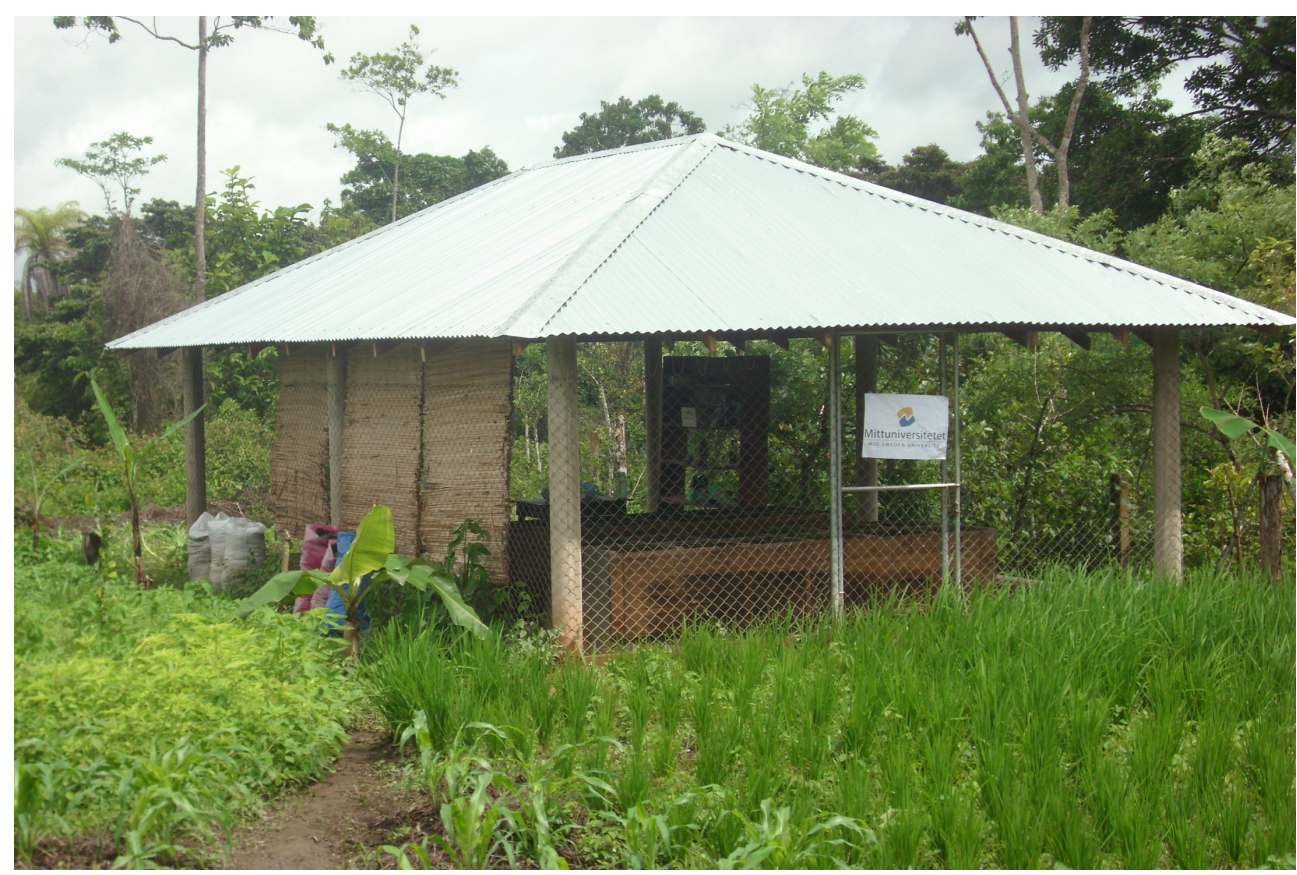

Figure 5. Mid Sweden University's experimental station at Casa Montesano in Nicaragua.

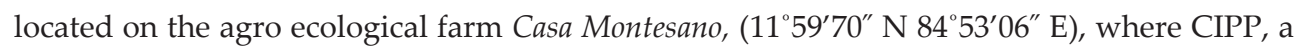
local NGO, dedicated to sustainable rural development projects has its headquarters. The region has a humid tropical climate with an average precipitation of $2000 \mathrm{~mm}$ per year and an annual average temperature between 25 and $28^{\circ} \mathrm{C}$. The soil on the experimental site is classified 
as ultisol, a common soil in the humid tropics occupying about $8 \%$ of the global ice-free land area and supporting $18 \%$ of the world's population.

Figure 6 shows the 24 compartments that were built in concrete with a smooth cement plaster in two sets of twelve compartments each. The compartments were built to fit $150 \mathrm{~L}$ each of agriculture soil. The purpose of the closed compartments is to test sustainable remediation methods in conditions as similar to in-situ remediation as possible without risks for pollutants to escape into nature. All technologies assessed in the experimental station are designed to be low cost/low technology methods, appropriate to economically marginalised people in developing countries. Notable is the use of locally available organic waste or by-products such as whey, pyroligneous acid and compost teas that can be achieved at a very low cost. The pilot scale research aim to find practical solutions to the obstacles that emerge when positive results from the laboratory are to be reproduced in the field. This implies dealing with issues like chemotaxis limitations, i.e. the importance of biodegrading microorganisms to be in close proximity to the pollutant. That can be achieved by the use of surfactants and solvents and by avoiding clogging of the soil pores.

The first experiment conducted in the station was on soil spiked with diesel at a concentration

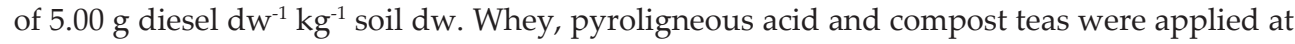
a high and a low dose on day $3,18,32,46,60,74$ and 88 after diesel contamination. The doses were adjusted to reflect the expected ideal dose (high) and an economically more viable dose (low). Soil samples were taken on day 2, 7, 12, 17, 31, 45, 59, 73, 87 and 101 after diesel contamination. Leachate water samples were collected by the end of the experiment in order to detect presence of metabolic by-products.

When this chapter was written the soil samples were not yet analyzed. The soil samples will be analysed by GC/FID to determine the effect on degradation from the different amendments. The amendments' effect on the microbial composition will subsequently be analysed by molecular methods. Whey has engendered significant enhancement of the degradation of aliphatic and aromatic hydrocarbons in previous laboratory experiments within our research group but compost tea and pyroligneous acid have not been previously tested.

In an upcoming project the research group envisages to use the experimental station for novel research on relevant pesticides. Many of the least biodegradable pesticides are relatively persistent to aerobic degradation [27] which poses additional challenges for in-situ remediation. These challenges will be addressed constructively in trials with redox barriers and other strategies.

\subsection{Experiences from in-situ remediation trials in remote areas of Northern Sweden}

\subsubsection{Bioremediation field trial using whey treatment of diesel contaminated soil at a former gas station in Northern Sweden}

A field experiment was carried out at a diesel contaminated site in Gäddede, in the county of Jämtland, north-western Sweden $\left(65^{\circ} 30^{\prime} \mathrm{N}, 1^{\circ} 09^{\prime} \mathrm{E}\right)$ [51], see figure 7 . The contaminated site is an old fuel station, established in the 1960:s. The contaminated site is about $10 \mathrm{~m}^{2}$ in area 


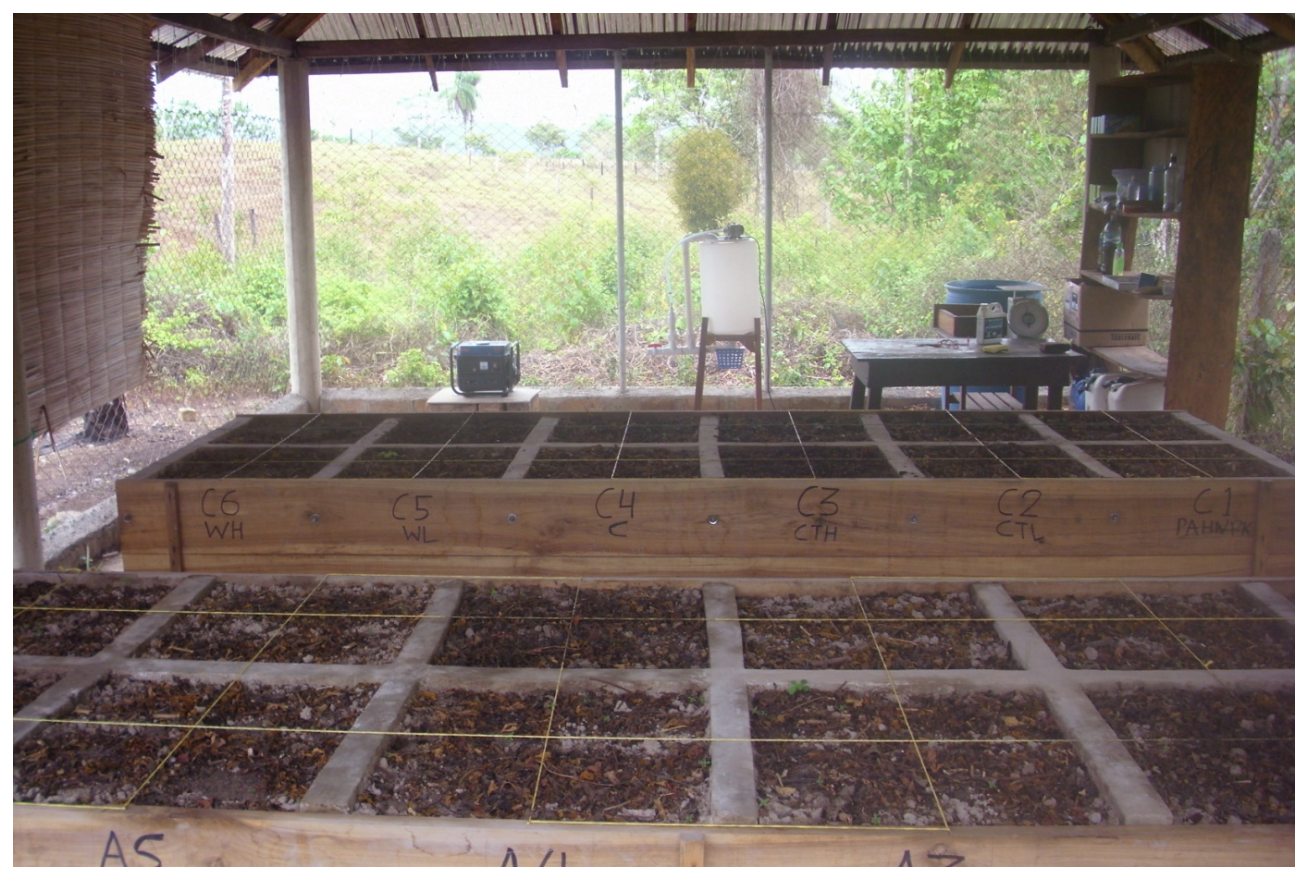

Figure 6. The compartments filled with soil at the experimental station in Nicaragua.

and about $0.5 \mathrm{~m}$ in depth. Previous investigations had pointed out an area with relatively high loads of aliphatic and aromatic hydrocarbons $C_{5}-C_{35}$ (approximately $2200 \mathrm{mg} \mathrm{kg}^{-1} \mathrm{dw}$ soil) dominated by diesel range aliphatics.

This site is representative of the many small contaminated areas that are spread out in rural areas, and are typically considered low priority sites. According to a study by the Swedish EPA in 2006 excavation and transport was the dominating remediation technology in Sweden [52] which is also the case in the county of Jämtland. In this case the distance from Gäddede to Gräfsåsen, the nearest approved treatment plant for contaminated soil, is $230 \mathrm{~km}$. The alternative of excavation and transport will therefore be expensive and contribute to air pollution and greenhouse gas emissions. For such areas, a low cost, easy to apply in-situ remediation technique would be appropriate. In-situ whey treatment might be such a method. Addition of whey to increase biological activity in soil for remediation purposes has been previously demonstrated in laboratory studies [12, 13, 18].

\subsubsection{Life cycle assessment of in-situ bioremediation with whey treatment in Gäddede in comparison} to traditional excavation and composting

In order to compare the two alternative treatment strategies, a screening life cycle assessment model was set up. The purpose was to investigate the environmental performance of the whey method, to benchmark the whey method towards the excavation and composting practice and 


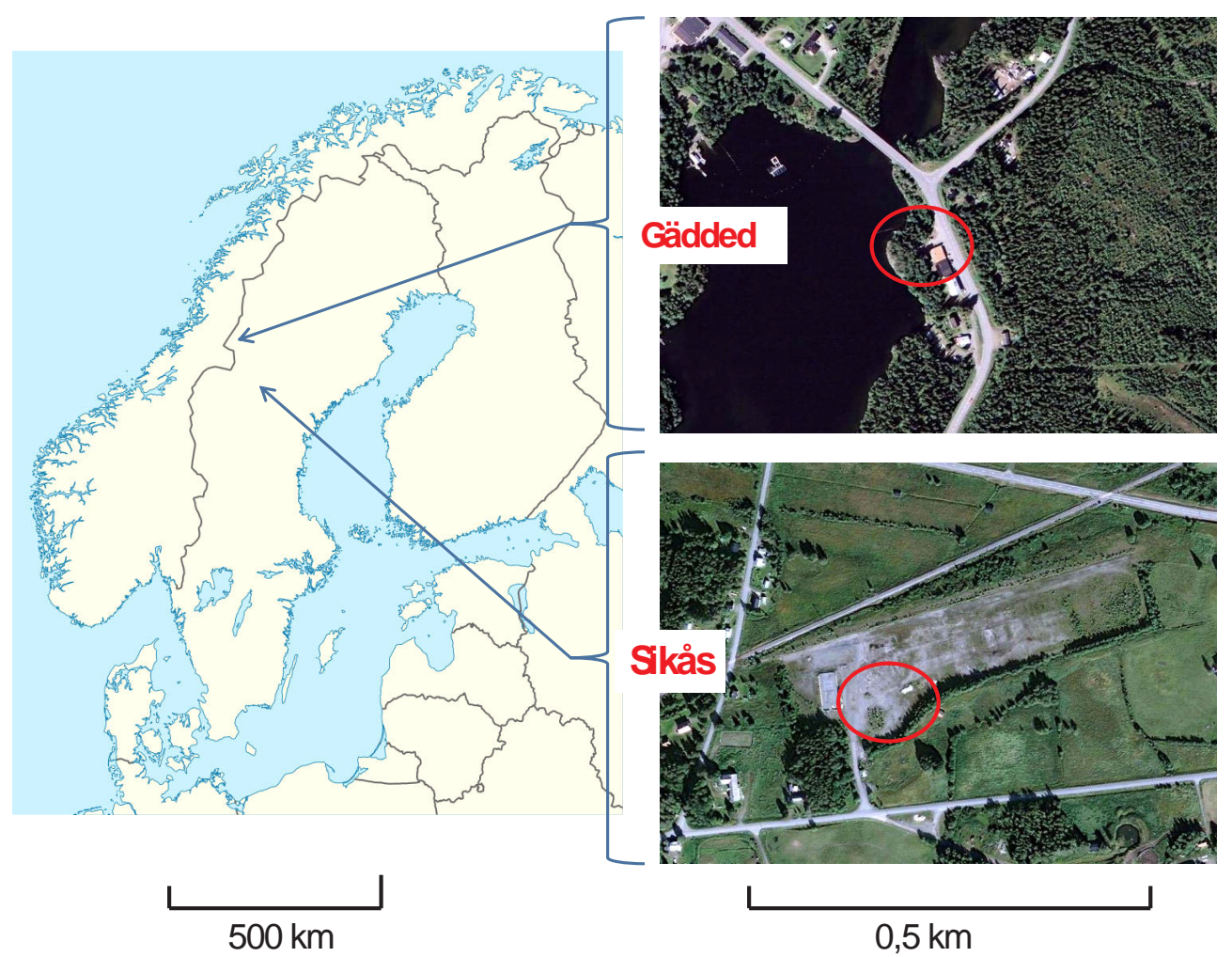

Figure 7. The test spots for in-situ bioremediation trials with whey in northern Sweden. (Location map of Scandinavia by NordNordWest licensed under the Creative Commons Attribution-Share Alike 3.0 Unported) Top picture: Diesel contaminated site at former gasoline station in Gäddede (Village). Bottom picture: Oil spot at lumberyard in Sikås (Village). (c) Lantmäteriet 2012/1067.

to identify environmental hot spots in the whey treatment life cycle [53]. The functional unit of this study was the treatment of $5 \mathrm{~m}^{3}$ of contaminated soil reaching a diesel concentration of $500 \mathrm{mg} \mathrm{kg}^{-1} \mathrm{dw}$ (upper limit in generic guidelines for "non sensitive areas"). For impact assessment the results are characterized as global warming potential (GWP), acidification potential (AP), eutrophication potential (EP) and photo oxidant creation potential (POCP). It was assumed that whey is added together with commercial fertilizer to avoid macronutrient deficit. Since the biological activity only takes place when it is warm enough (this mountainous region has a cold climate with at least 6 months of winter and a yearly average temperature of around $0^{\circ} \mathrm{C}$ ) the total treatment time was estimated to two summers. The alternative treatment assumed in this study is to excavate the $5 \mathrm{~m}^{3}$ of contaminated soil at the site in Gäddede, transport it to the waste treatment site in Gräfsåsen, Östersund, Sweden, and compost the soil in windrows after mixing the soil with manure. The windrows are turned using an excavator and when the concentrations of contaminants are low enough the compost is used as top cover 
of a landfill. Figure 8 illustrates a simplified model of the life-cycle process flow diagram for the whey treatment scenario.

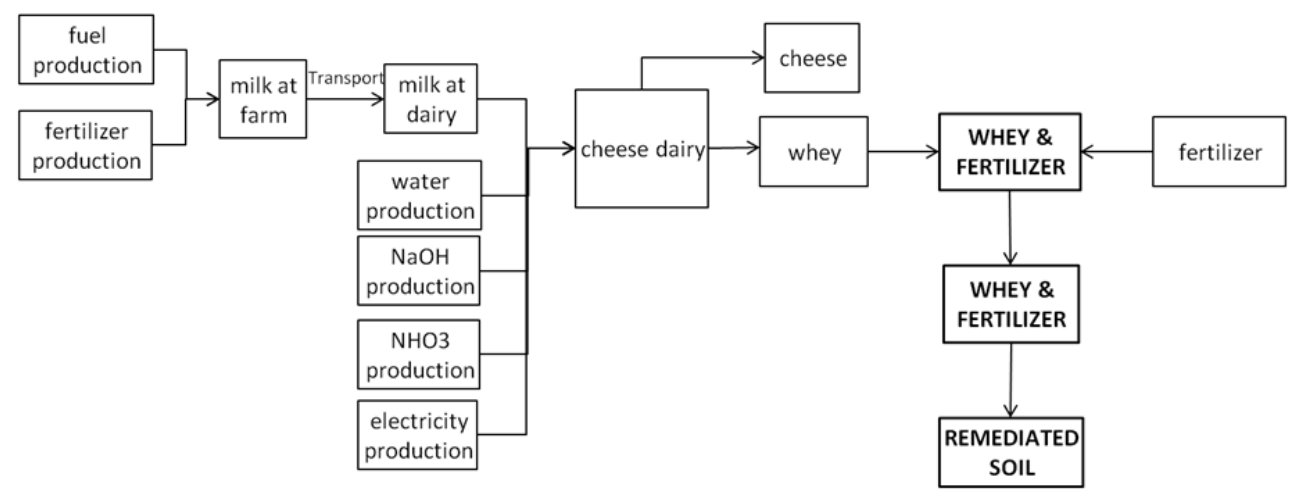

Figure 8. The life cycle inventory model of the whey scenario (From [53]).

The hydrocarbon pollution in the $5 \mathrm{~m}^{3}$ soil to be treated (over an area of $10 \mathrm{~m}^{2}$ ) was assumed to be the same in the whole mass of soil i.e. $2200 \mathrm{mg} \mathrm{kg}^{-1} \mathrm{dw}$. Comparisons with laboratory results [12] indicate that an addition of $210 \mathrm{mg} \mathrm{dw}$ whey $\mathrm{kg}^{-1}$ diesel polluted soil might give a sufficient reduction in diesel oil contamination to reach the higher target value of $500 \mathrm{mg}$ $\mathrm{kg}^{-1} \mathrm{dw}$ [54]. This gives a calculated need of about $2 \mathrm{~kg} \mathrm{dw}$ whey, equivalent to $367 \mathrm{~L}$ of whey $\left(5.5 \mathrm{~g} \mathrm{dw} \mathrm{L}^{-1}\right)$ for the area to be treated. The laboratory tests also indicate that a number of successive additions of whey will give a better degradation compared to one large addition, and eight additions (46 L of wet whey per addition) spaced out with 14 days in between was assumed to be a good practice. The total time needed for the degradation is from the laboratory tests estimated to 167 days. Since on-site biodegradation will only take place when it is warm enough [13] the degradation was assumed to take place during two summer months each year for two years. To ensure that biodegradation is not limited by macronutrient deficiencies addition of commercial fertilizer was assumed. It was estimated that a one-time addition of $1.5 \mathrm{~kg}$ YaraMila 18-4-14 would provide the necessary nutrients. During the remediation process whey and fertilizer was assumed to be manually added to the contaminated area. Whey additions of 46 L every 14 day over a period of two subsequent summers were assumed.

For the intended bioremediation a total of $2 \mathrm{~kg} \mathrm{dw}$ whey is needed. Data on cheese and whey production was obtained from Milko dairy in Östersund. To produce 0.9 ton of Edam cheese and 1 ton of dry whey the cheese dairy on average requires $11000 \mathrm{~L}$ of milk. Inventory data was gathered to describe the use of average Swedish electricity, water and auxiliary chemicals [55]. Inventory data for milk production, including farming activities, transports and dairy operations was based on a LCI by the Swedish Diary Association.

Since whey is a by-product of cheese production, economic allocation was used giving an allocation of $80 \%$ on cheese and $20 \%$ on whey. In a sensitivity analysis the results were 
investigated, assuming that all production environmental impact is allocated to the whey. The fertilizer production is described using emissions data on the production of $1 \mathrm{~kg}$ of fertilizer. Whey and fertilizer will have to be transported to the contaminated site. Whey is produced in Sweden by Milko AB is transported over a distance of $230 \mathrm{~km}$ from Östersund to Gäddede. Fertilizer is obtained from commercial fertilizer store and transported the same distance. Environmental impacts from the transports were calculated using emissions factors assuming a light distribution truck, Euro 2, vehicle manufactured during 1996-2000.

Figure 9 illustrates a simplified model of the life-cycle process flow diagram for the excavation and composting treatment scenario. Assuming a soil density of $1922 \mathrm{~kg} \mathrm{~m}^{-3}$ for the $5 \mathrm{~m}^{3}$ soil to be treated (over an area of $10 \mathrm{~m}^{2}$ ) the calculated mass of contaminated soil was 9.6 ton.

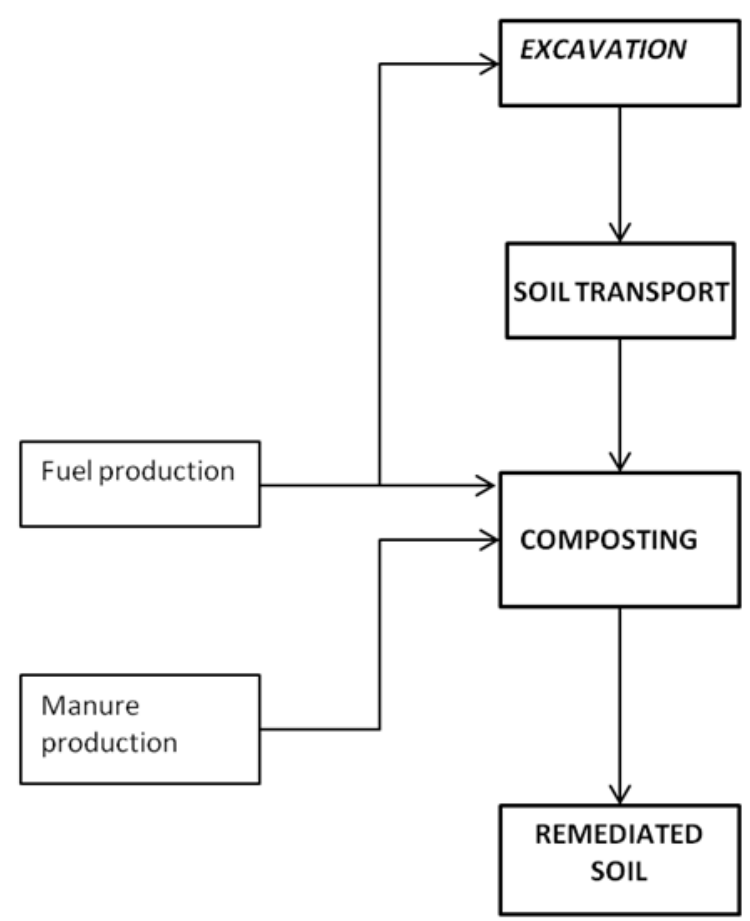

Figure 9. The life cycle inventory model of the excavation and composting scenario (From [53]).

It was assumed that the Gäddede case would need a 14 ton excavator for 15 minutes and use $2 \mathrm{~L}$ of diesel. Production of the diesel oil was described by inventory data from [56]. The excavated soil will then have to be transported $230 \mathrm{~km}$ from Gäddede to Östersund to a composting plant. Impacts from the transport is described using emission factors for a medium sized distribution truck with a payload of 8.5-14 ton, Euro class 2, produced between 1996 2000. 


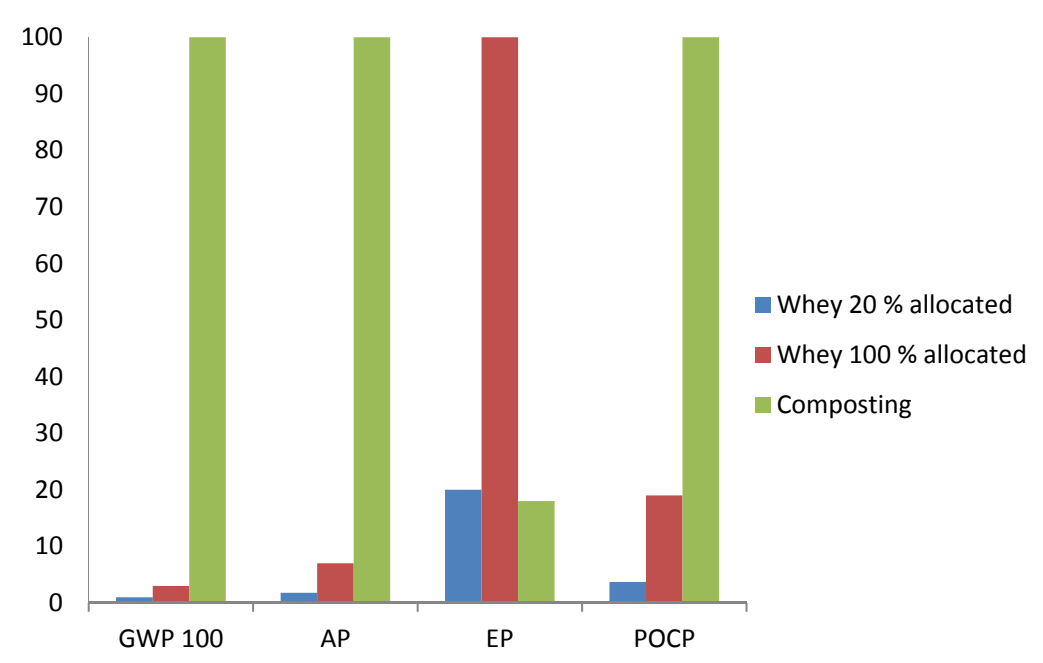

Figure 10. Results from the LCA models for the in-situ whey treatment scenario - with two levels of allocation of the whey production - and the excavation and off-site composting scenario. GWP 100, Global Warming Potential, 100 year time horizon; AP, Acidification Potential; EP, Eutrophication Potential; POCP, Photochemical Ozone Creation Potential. The allocation scenarios mean that respectively 20 and $100 \%$ of the environmental effect of the cheese production was allocated to the whey. Normalized data, the highest result in each category is set to 100\% (From [53]).

At Gräfsåsen, the waste treatment and landfill in Östersund, the contaminated soil is mixed with horse manure and placed in windrows in a string-like arrangement. Over the period 2005 to 2009 some 2320 tons of contaminated soil and 1560 tons of manure have been received at the composting plant in Gräfsåsen, giving an average manure use of 0.67 ton/ton. For the manure transport we assume the same emission factors as for the soil transport and an average transport distance of $50 \mathrm{~km}$. The manure generations are totally allocated to the horse keeping. Every one month during the summer the windrows are mixed using a mixer mounted on a wheel loader. For this process half the environmental impact from the excavation in Gäddede was assumed. Use of the treated compost as cover of the land fill is not assumed to be connected to any environmental impacts. The results from the whey treatment scenario and the composting scenario for the four impact categories GWP, AP, EP and POCP is shown in Figure 10 , together with the results from the sensitivity analysis where all environmental impacts from milk production and the cheese dairy are allocated to the whey.

For the GWP, AP and POCP impact categories the whey scenarios give lower results than the excavation and off-site composting scenario, whereas the EP category shows higher results. The EP result for the whey treatment is totally dependent on the whey production chain and originates at the farm (such as nutrient runoff, ruminating cattle, vaporization of ammonia from manure) or by the production of materials used at the farm (such as fertilizers). The milk farm activity is the most contributing in the whey scenario for all four impact categories shown. 
When comparing the allocated and the unallocated whey treatment scenarios the milk-cheese chain has a rather large impact, especially for eutrophication (EP in diagram). It should be noted that the transport of whey and fertilizer for the whey scenario is described with emission factors of a truck transport, that means it is assumed to have the necessary whey and fertilizer as part of the load of the truck and the off-loading will be part of a delivery route where other parts of the load will be off-loaded in other places. Arranging good logistics is thus important both for the whey treatment and for the excavation and transport to off-site composting.

\subsubsection{Results of bioremediation field trials and microcosm experiments using whey treatment of the contaminated soil in Gäddede}

The result from whey treatment of the polluted site during a $3 \frac{1}{1} 2$ months field experiment was not promising. The experiment was initiated 10 May when the snow had melted and the soil temperature at $18 \mathrm{~cm}$ depth was $5{ }^{\circ} \mathrm{C}$. The polluted area was given an initial dose of $545 \mathrm{~g}$ $\mathrm{m}^{-2} \mathrm{NPK}$ fertilizer $(18 \% \mathrm{~N} ; 4 \% \mathrm{P} ; 10 \% \mathrm{~K})$ followed by bi-weekly doses of $3.2 \mathrm{~L} \mathrm{~m}^{-2}$ milk whey [51]. During the course of the summer the soil temperature rose to a maximum of $15^{\circ} \mathrm{C}$ in the beginning of August and dropped thereafter. When the experiment was ended in mid August no detectable reduction of soil hydrocarbons was observed.

In parallel to the field experiment, microcosm studies were carried out on soil samples, from the vicinity of the contaminated site that had been artificially contaminated with diesel fuel. In the microcosms the soil was subjected to the same treatment as in the field study with the only difference that the soil was kept at $22{ }^{\circ} \mathrm{C}$. During these conditions the diesel range aliphatics was almost completely degraded within 60 days. This is in accordance with previous studies on hexadecane that showed significant difference in degradation rates at 7 and $22{ }^{\circ} \mathrm{C}$ respectively [13]. Soil temperature is probably the most limiting factor for in-situ bioremediation in cold regions and the short period of warmth during 3 summer months is rarely enough to bring the soil temperature to levels that give sufficient rates of biodegradation. A possible way to circumvent this problem would be to heat up the soil with heat injection. Preliminary calculations carried out at our department reveal that the electric power needed to heat up a $100 \times 100 \times 2 \mathrm{~m}$ contaminated volume of polluted soil from 8 to $25^{\circ} \mathrm{C}$ by e.g. a sufficient number of heat rods, would be $166 \mathrm{~kW}$ during a one month period corresponding to an input heating energy of $98 \times 10^{3} \mathrm{kWh}$. The calculation assumed that the soil surface was insulated and that there were no vertical and downwards heat losses during the heat-up period. The energy needed to maintain the temperature at $25^{\circ} \mathrm{C}$ for another 11 month period assuming horizontal and vertical (downwards) heat losses would amount to $235 \times 10^{3} \mathrm{kWh}$. Total energy need for a one year period is then $333 \times 10^{3} \mathrm{kWh}$. The following input data was used: A linear temperature drop distance of $9.1 \mathrm{~m}$ to ambient temperatures, heat conductivity $1.5 \mathrm{~W} \mathrm{~m}^{-1} \mathrm{~K}^{-1}$, specific heat capacity $800 \mathrm{~J} \mathrm{~kg}^{-1} \mathrm{~K}^{-1}$ and soil density $1300 \mathrm{~kg} \mathrm{~m}^{-3}$. These are rough calculations based on some simplified assumptions about heat transfer in soil but may still give an estimate of the magnitude of the input energy needed for a temperature enhanced in-situ soil bioremediation project in cold climate. Downscaled to the $10 \mathrm{~m}^{2}$ by $0.5 \mathrm{~m}$ of the Gäddede diesel oil plot the corresponding figures would be 27 and $387 \mathrm{kWh}$ respectively for the heating and 11 months maintenance input energy need respectively giving a total energy need for a 12 month period 
of roughly $414 \mathrm{kWh}$. Part of this energy need could easily be provided by solar panels. Furthermore, taking into consideration the very rapid increase in degradation rate even at a moderately elevated temperature such as $22{ }^{\circ} \mathrm{C}$ it is possible that a successful temperature enhanced remediation of the Gäddede plot could even be carried out within 6 months during a period when solar panels can provide the total need of input energy. Solar panels can easily be moved from one project to another so the technology described here should have a potential for application in in-situ soil bioremediation in remote places and in cold regions.

\subsubsection{One-time application of whey to oil spot at a lumberyard in Sikas}

An experiment was carried out to test a low-cost and low-tech solution for remediation of soil contaminated by waste motor oil in a cold region. A $10 \mathrm{~m}^{2}$ spot that had been polluted by leakage from a $200 \mathrm{l}$ barrel with used motor oil was chosen for the experiment. This spot would certainly come up low in the priority list for remediation projects due to its location in a remote region in the northern parts of the county of Jämtland and also due to the scale of the pollution in proportions to the costs of traditional remediation practices. Such spots are however far from uncommon and the total impact from the highly toxic substances found in waste oil, such as carcinogenic $\mathrm{PAH}$, may be significant. The polluted area was within a timber terminal and the soil was covered with highly compacted sand and gravel. The amount of waste oil that had leaked from the corroding barrel was estimated to $100 \mathrm{~L}$. The permeability of the soil was very low and the oil had penetrated the soil to a depth of approximately10 mm or less. Samples from the plot showed that the oil mainly consisted of high molecular weight aliphatics and aromatics $\mathrm{C}_{16}-\mathrm{C}_{35}$.

The oil spot was divided in two parts separated by a shallow cut made by the shovel that can be seen in the top picture in Figure 11. $200 \mathrm{~L}$ of fresh milk whey was applied to the left side of the spot. The plot had a slight slope to the left and to the front in the picture. Approximately $50 \%$ of the whey was lost by runoff in these directions due to the low permeability of the soil but some whey crossed the notch made by the shovel and penetrated the right part of the plot. The dashed line in the figure separates the treated left part of the plot from the untreated, right part of the plot. To make sure that lack of macronutrients would not limit the biodegradation a total of $6 \mathrm{~kg}$ commercial granulated fertilizer (N/P/K 18/4/10) was evenly applied to the whole spot (treated and control).

The photo from April 2007 was taken just before treatment. The snow had just melted and the average air temperature during April is around $2{ }^{\circ} \mathrm{C}$ at this latitude and rose to $15^{\circ} \mathrm{C}$ during July, which is also normal for these latitudes. It is plausible that the soil surface could reach higher temperatures during a few hot summer days and that the dark colour of the oil would enhance heat absorption in such cases. Nevertheless, one year later, in May 2008, no difference whatsoever could be observed between treated and untreated spot, see middle picture in Figure 11 (note snow remaining in May).

The bottom picture in Figure 11 shows the plot two years and two months after application of whey to the left part. There is a remarkable difference between the darkness of the sectors and clearly, degradation of the oil in the treated part had commenced. The person in the picture indicating the divine between the light and the dark side of the plot had no a priori knowledge 
of the treatment strategy. Soil samples taken from the sectors indicate that the TPH concentration in the left part is half the concentration in the untreated part.

The long term effect of a one-dose of the liquid amendment (whey) is remarkable. It is worth to note that the summer 2008 was hotter than normal in the region and the monthly average temperature anomaly in July was $+1.5{ }^{\circ} \mathrm{C}$ according to the Swedish Meteorological and Hydrological Institute, www.smhi.se/klimatdata/meteorologi. Clearly the low soil temperature in this, just as in the above presented case, severely limits the rate of biodegradation, but when conditions becomes thermodynamically more favourable, the microorganisms are able to benefit from the extra carbon and micronutrients provided by the amendment, even after a one year incubation time.

\section{Opportunities and future predictions of soil remediation}

Remediation of contaminated soils is presently a costly venture but as new technologies emerge to treat soils in-situ, expenses can diminish considerably. Technology optimists like Ray Kurzweil forecast that pollution will discontinue to be produced in the future and predicts a set of technologies (including biotechnologies) that will beused to clean up the previously generated contamination. Kurzweilexpresses a strong faithinnanotechnology that he believes will provide useful features for remediation of contaminants including; improved catalysis, chemical and atomic bonding, sensing, and mechanical manipulation. Currently, extensive research is undertaken to develop nanoproduced crystalline materials for catalysts that have the potential to improve chemical yields, reduce toxic by-products, and remove contaminants [59].

To overcome some of the difficulties to degrade recalcitrant compounds research on combined biological/abiological degradation technologies might provide useful technologies. Pretreatments by strong oxidizing agents such as ozone, Fenton's reagent, potassium permanganate, ferrate etc. have shown promising results and Singh and Ward predict that combined chemical/biological treatment of pollutants will play an important role in the future [45]. Strong chemical oxidants may however severely affect soil microbial populations and furthermore requires input of energy and material resources.

The use of biocatalysts is another interesting method whose practical applications have been predicted to increase in the future. This kind of enzymatic remediation can potentially overcome difficulties such as low survival rate of whole cell organisms and generation of toxic by-products that are associated with bioaugmentation. Research on enzymatic bioremediation is at its infancy and few field studies exist. The major limitation for large-scale applications is currently the prohibitive cost for the production of the enzymes. Molecular tools are increasingly explored to overcome that obstacle which could decrease the costs significantly in the future [60]. As we have demonstrated in this chapter the use of readily available organic waste products as amendments and the appropriate application of principles of ecological engineering is potentially a way to make bioremediation more sustainable. 


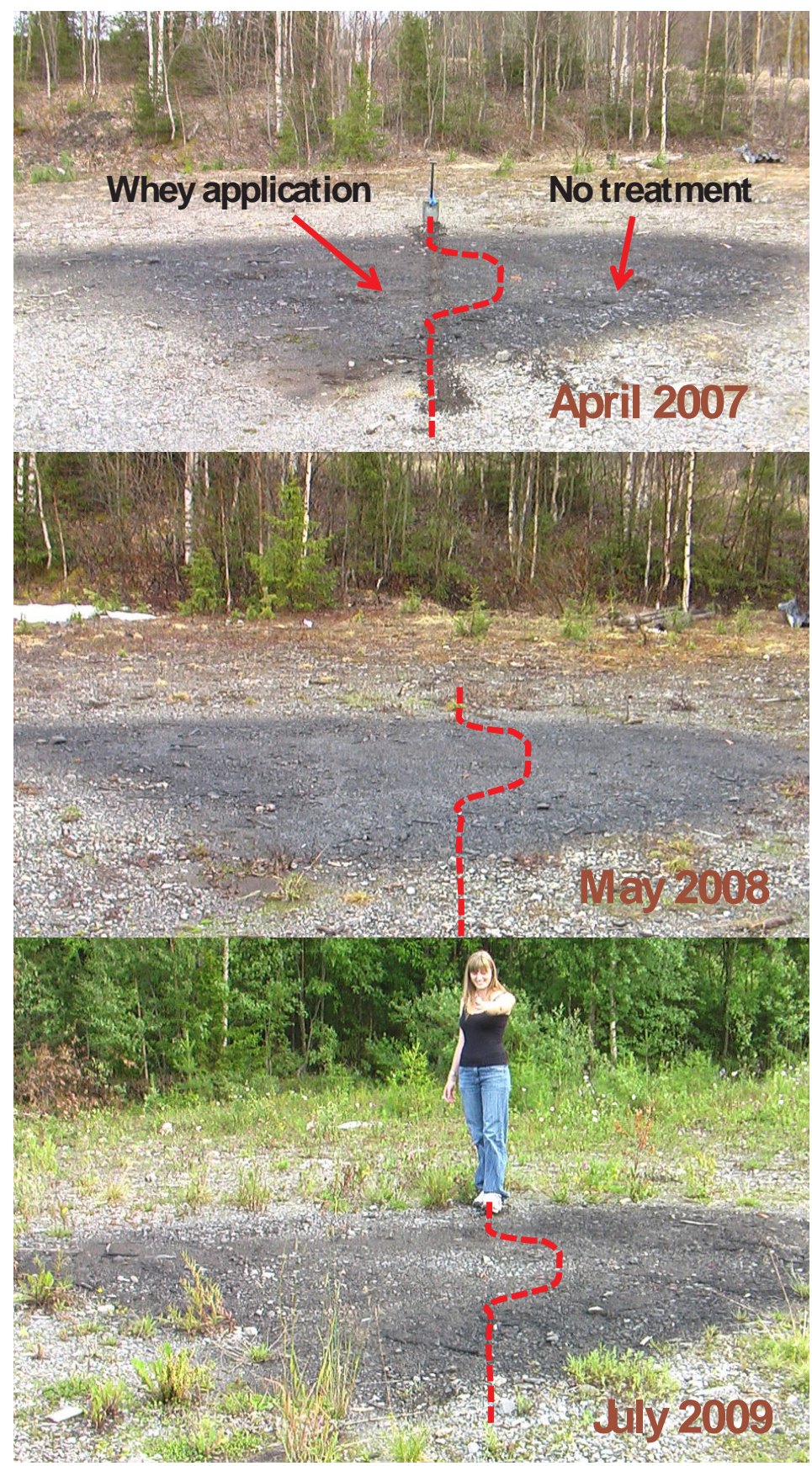

Figure 11. One time treatment of left part of oil spot with 200 I fresh milk whey. 


\section{Conclusion}

It is a common belief that soil remediation is a sustainable industry but many remediation projects use vast amounts of energy and often physically damage the remediation site by removing its topsoil. Ecological Engineering can potentially make remediation projects more sustainable. The large embodied energy in many organic pollutants may be used as a driver of a self-designing in-situ remediation process by indigenous microorganisms in the soil.

The intrinsic capacity of soil microbial communities to initiate and accelerate degradation of soil pollutants rely on the fundamental thermodynamic driving force towards complete degradation of target organic pollutants to low molecular-weight inorganic compounds such as carbon dioxide and water. The degradation process releases quantities of useful "free" energy that can be used by soil microorganisms in their metabolism. Figure 1 illustrates this together with important abiotic and biotic degradation pathways and intermediate storages. Table 1 gives some numbers to illustrate the theoretical "energy gain" by degrading organisms as they catabolise representative soil pollutants. Turnover times for organic pollutants are typically short in the atmosphere, e.g. hours-days [61] but considerably longer in soil, e.g. months-decades $[7,44]$ mainly because of lack of photochemistry in the subsurface of the soil. The slow biodegradation kinetics in soil can however be considerably improved by the use of locally available waste materials, such as whey and fermented whey that stimulate microbial activity, figure 2 and table 2. There are a number of other waste materials that have been successfully tested by us [12-14, 18] or others [26-28] or remain to be tested (figure 3). Remediation strategies based on amendments from locally available by-products can be tailored to suit site-specific conditions and be adapted to a wide range of climates and contexts as illustrated in the case studies presented in this chapter.

Concepts of Ecological engineering, i.e. measures to stimulate the self-organizing capacity of ecosystems by the use of organic amendments, conservation of non-renewable energy resources and ecosystem conservation by in-situ treatment with locally available waste resources have the potential of making soil remediation projects in low priority sites in developing countries and in remote regions more sustainable than conventional methods that rely on costly and less environmentally benign technology. Life cycle assessment (LCA) was used to evaluate the different remediation technologies from a systems perspective. Results of the screening LCA study of the whey treatment method versus a conventional dig-transportcompotation scenario at a remote diesel oil polluted site in Northern Sweden (See map, Gäddede, figure 7) are shown in figure 10. Clearly, the in-situ whey treatment has an overall lower environmental impact compared to the transport-composting method. The most contributing activity for the composting scenario in all of the environmental impact categories studied was the transport of the excavated soil to the composting site. Thus the transport distance is of large importance. For sites where the transport distance is much shorter, the composting scenario would come out much better. This outcome is in accordance with what has been earlier reported by Suèr et al [57] and Toffoletto et al [58] that transportation and transport distance is a key element when choosing between in-situ and ex-situ remediation technology. 
In this chapter we have demonstrated that Ecological engineering in concurrence with the application of basic thermodynamic principles and kinetic modelling of data from laboratory experiments can provide useful guidelines for the development of energy conserving and economically feasible bioremediation technologies. Such technologies have the potential of making in-situ bioremediation of polluted soil in low priority sites in developing countries and in remote regions more sustainable.

\section{Acknowledgements}

We gratefully acknowledge the financial support of the European Union Regional Development Fund. We are indebted to Morgan Fröling and Joseph Akambih Tajam for conducting the LCA screening analysis of the whey method and to Anja Wedermeyer and Sylvia Vespermann for calculating energy need for temperature-enhanced bioremediation in cold regions.

\section{Author details}

Anders Jonsson* and Henrik Haller

*Address all correspondence to: anders.jonsson@miun.se

Department of Ecotechnology and Sustainable Building Engineering, Mid Sweden University, Sweden

\section{References}

[1] Mudhoo A, Mohee R. Elements of Sustainability and Bioremediation. In: Bioremediation and Sustainability. John Wiley \& Sons, Inc.; 2012..s. 1-41.

[2] Lynch JM, Moffat AJ, Lynch JM, Moffat AJ. Bioremediation - Prospects for the Future Application of Innovative Applied Biological Research. Ann. Appl. Biol.; 146(2:217-21.

[3] Vidali M. Bioremediation, An Overview. Pure and Applied Chemistry 2001;73(7): 1163-72.

[4] Mitsch WJ. What is Ecological Engineering? Ecological Engineering 2012;45(0):5-12.

[5] Mitsch WJ, Jørgensen SE. Ecological Engineering and Ecosystem Restoration. Wiley; 2004. 
[6] Green AE, Voordouw G. Microbial Community Dynamics During Bioremediation of Hydrocarbons. In: Singh A, Ward OP. (eds) Biodegradation and Bioremediation. Berlin: Springer-Verlag; 2004.

[7] Riser-Roberts E. Remediation of Petroleum Contaminated Soils. Boca Raton: Lewis Publishers; 1998.

[8] Peng RH, Xiong AS, Xue Y, Fu XY, Gao F, Zhao W, et al. Microbial Biodegradation of Polyaromatic Hydrocarbons. FEMS Microbiology Reviews 2008;32(6):927-55.

[9] Solomons SD, Qin D, Manning M, Chen Z, Marquis M, Averyt KB, et al. Technical Summary. In: Climate Change 2007: The Physical Science Basis. Contribution of Working Group I to the Fourth Assessment Report of the Intergovernmental Panel on Climate Change. Cambridge, United Kingdom and New York, USA: Cambridge University Press; 2007.

[10] Mohn WW. Biodegradation and Bioremediation of Halogenated Organic Compounds. In: Sing A, Ward AP. (eds) Biodegradation and Bioremediation. Berlin, Heidelberg, New York: Springer 2004..p. 125-48.

[11] Adriano DC, Bollag JM, Frankenberger WT, Sims RCJ. (eds) Bioremediation of Contaminated Soil. Madison: American Society of Agronomy; 1999.

[12] Östberg TL, Jonsson AP, Bylund D, Lundström US. The Effects of Carbon Sources and Micronutrients in Fermented Whey on the Biodegradation of n-Hexadecane in Diesel Fuel Contaminated Soil. International Biodeterioration \& Biodegradation 2007;60(4):334-41.

[13] Östberg TL, Jonsson AP, Lundström US. Enhanced Degradation of n-Hexadecane in Diesel Fuel Contaminated Soil by the Addition of Fermented Whey. Soil and Sediment Contamination: An International Journal 2007;16(2):221-32.

[14] Östberg TL, Jonsson AP, Lundstrom US. Accelerated Biodegradation of n-Alkanes in Aqueous Solution by the Addition of Fermented Whey. International Biodeterioration \& Biodegradation 2006;57(3):190-4.

[15] Brunner W, Focht DD. Deterministic Three-Half-Order Kinetic Model for Microbial Degradation of Added Carbon Substrates in Soil. Applied and Environmental Microbiology 1984;47(1):167-72.

[16] Mohn WW, Stewart GR. Limiting Factors for Hydrocarbon Biodegradation at Low Temperature in Arctic Soils. Soil Biology \& Biochemistry 2000;32:1161-72.

[17] Brown AM. A Step-by-step Guide to Non-linear Regression Analysis of Experimental Data Using a Microsoft Excel Spreadsheet. Computer Methods and Programs in Biomedicine 2001;65(3):191-200. 
[18] Jonsson AP, Östberg TL. The Effects of Carbon Sources and Micronutrients in Whey and Fermented Whey on the Kinetics of Phenanthrene Biodegradation in Diesel Contaminated Soil. Journal of Hazardous Materials 2011;192(3):1171-7.

[19] Reddy N, Yang Y. Biofibers From Agricultural Byproducts for Industrial Applications. Trends in Biotechnology 2005;23(1):22-7.

[20] Ulloa JB, van Weerd JH, Huisman EA, Verreth JAJ. Tropical Agricultural Residues and their Potential Uses in Fish Feeds: the Costa Rican Situation. Waste Management 2004;24(1):87-97.

[21] Ruane J, Sonnino A. Agricultural Biotechnologies in Developing Countries and their Possible Contribution to Food Security. Journal of Biotechnology 2011;156(4):356-63.

[22] Aregheore EM. Chemical Composition and Nutritive Value of Some Tropical Byproduct Feedstuffs for Small Ruminants - In Vivo and In Vitro Digestibility. Animal Feed Science and Technology 2000;85(1-2):99-109.

[23] Singh H. Mycoremediation: Fungal Bioremediation. Wiley; 2006.

[24] Eggen T. Application of Fungal Substrate from Commercial Mushroom Production Pleuorotus Ostreatus - for Bioremediation of Creosote Contaminated Soil. International Biodeterioration \& Biodegradation 1999;44(2-3):117-26.

[25] Jayasinghe P, Hawboldt K. A Review of Bio-Oils from Waste Biomass: Focus on Fish Processing Waste. Renewable and Sustainable Energy Reviews 2012;16(1):798-821.

[26] Dzul-Puc JD, Esparza-García F, Barajas-Aceves M, Rodríguez-Vázquez R. Benzo(a)pyrene Removal from Soil by Phanerochaete Chrysosporium Grown on Sugarcane Bagasse and Pine Sawdust. Chemosphere 2005;58(1):1-7.

[27] Velázquez-Fernández JB, Ramírez-Sandoval M, Domínguez-Ojeda D, Martínez-Rizo AB. Biodegradation and Bioremediation of Organic Pesticides. Intech: 2012..http:// www.intechopen.com/books/pesticides-recent-trends-in-pesticide-residue-assay/ biodegradation-and-bioremediation-of-organic-pesticides (acessed 22 October 2013)

[28] Al-Hadhrami MN, Lappin-Scott HM, Fisher PJ. Studies on the Biodegradation of Three Groups of Pure n-Alkanes in the Presence of Molasses and Mineral Fertilizer by Pseudomonas Aeruginosa. Marine Pollution Bulletin 1997;34(11):969-74.

[29] Steiner C, Das KC, Garcia M, Förster B, Zech W. Charcoal and Smoke Extract Stimulate the Soil Microbial Community in a Highly Weathered Xanthic Ferralsol. Pedobiologia 2008;51(5-6):359-66.

[30] Mohan D, Pittman CU, Steele PH. Pyrolysis of Wood/Biomass for Bio-Oil: A Critical Review. Energy \& Fuels 2006;20(3):848-89.

[31] Zulkarami B, Ashrafuzzaman M, Husni MO, Ismail MR, Zulkarami B, Ashrafuzzaman M, et al. Effect of Pyroligneous Acid on Growth, Yield and Quality Improve- 
ment of Rockmelon in Soilless culture.(Report). Australian Journal of Crop Science; 5(12):1508.

[32] Spokas KA, Novak JM, Stewart CE, Cantrell KB, Uchimiya M, DuSaire MG, et al. Qualitative Analysis of Volatile Organic Compounds on Biochar. Chemosphere; 85(5):869-82.

[33] Chidumayo EN, Gumbo DJ, Chidumayo EN, Gumbo DJ. The Environmental Impacts of Charcoal Production in Tropical Ecosystems of the World: A synthesis. Energy for Sustainable Development.

[34] Zandersons J, Gravitis J, Kokorevics A, Zhurinsh A, Bikovens O, Tardenaka A, et al. Studies of the Brazilian Sugarcane Bagasse Carbonisation Process and Products Properties. Biomass and Bioenergy;17(3):209-19.

[35] FAO. Simple Technologies for Charcoal Making. Food and Agriculture Organization of the United Nations (Mechanical Wood Products Branch); 1983.

[36] Loo AY, Jain K, Darah I, Loo AY, Jain K, Darah I. Antioxidant Activity of Compounds Isolated from the Pyroligneous Acid, Rhizophora Apiculata. Food Chemistry;107(3):1151-60.

[37] Kadota M, Niimi Y, Kadota M, Niimi Y. Effects of Charcoal with Pyroligneous Acid and Barnyard Manure on Bedding Plants. Scientia Horticulturae;101(3):327-32.

[38] Yoshimura H, Washio H, Yoshida S, Seino T, Otaka M, Matsubara K, et al. Promoting Effect of Wood Vinegar Compounds on Fruit-Body Formation of Pleurotus Ostreatus. Mycoscience;36(2):173-7.

[39] Pant A, Radovich TJK, Hue NV, Arancon NQ. Effects of Vermicompost Tea (Aqueous Extract) on Pak Choi Yield, Quality, and on Soil Biological Properties. Compost Science \& Utilization 2011;19(4):279-92.

[40] St. Martin CCG, Brathwaite RAI. Compost and Compost Tea: Principles and Prospects as Substrates and Soil-Borne Disease Management Strategies in Soil-less Vegetable Production. Biological Agriculture \& Horticulture 2012;28(1):1-33.

[41] Ghorbani R, Koocheki A, Jahan M, Asadi GA. Impact of Organic Amendments and Compost Extracts on Tomato Production and Storability in Agroecological Systems. Agron. Sustain. Dev. 2008;28(2):307-11.

[42] Scheuerell SJ, Mahaffee WF, Scheuerell SJ. Variability Associated with Suppression of Gray Mold ( Botrytis cinerea ) on Geranium by Foliar Applications of Nonaerated and Aerated Compost Teas. Plant Disease;90(9):1201-8.

[43] Naidu YM, Sariah Kadir, Jugah; Siddiqui, Yasmeen. Microbial Starter for the Enhancement of Biological Activity of Compost Tea. International Journal of Agriculture and Biology 2010;12(1):51-6. 
[44] Alexander M. Biodegradation and Bioremediation. 2 ed. San Diego: Academic Press; 1999.

[45] Singh A, Ward OP. Biodegradation and Bioremediation. Berlin: Springer; 2004.

[46] Tognetti C, Laos F, Mazzarino MJ, Hernandez MT, Tognetti C, Laos F, et al. Composting vs. Vermicomposting: A Comparison of End Product Quality. Compost Sci. Util.;13(1):6-13.

[47] Sinha RK, Agarwal S, Chauhan K, Chandran V, Soni BK, Sinha RK, et al. Vermiculture Technology: Reviving the Dreams of Sir Charles Darwin for Scientific Use of Earthworms in Sustainable Development Programs. Technology and Investment; 1(3):155.

[48] González-Siso MI. The Biotechnological Utilization of Cheese Whey: A Review. Bioresource Technology 1996;57(1):1-11.

[49] Crawford R. Bioremediation. In: Dworkin M, Falkow S, Rosenberg E, Schleifer K-H, Stackebrandt E. (eds.) The Prokaryotes. Springer New York; 2006..p. 850-63.

[50] Eddleston M, Karalliedde L, Buckley N, Fernando R, Hutchinson G, Isbister G, et al. Pesticide Poisoning in the Developing World-A Minimum Pesticides List. The Lancet 2002;360(9340):1163-7.

[51] Vilches AP, Bylund D, Jonsson AP. Enhanced Natural Biodegradation of Diesel Fuel Contaminants in Soil by Addition of Whey and Nutrients. In: Proceedings of Linnaeus ECO-TECH '10; November 22-24..2010; Kalmar, Sweden; 2010.

[52] Naturvårdsverket. Åtgärdslösningar -Erfarenheter och Tillgängliga Metoder. Sweden: Naturårdsverket; 2006.

[53] Tajam JA, Fröling M, Jonsson AP. Small Scale In-situ Bioremediation of Diesel Contaminated Soil - Screening Life Cycle Assessment of Environmental Performance. In: Proceedings of Linnaeus ECO-TECH '10; November 22-24..2010; Kalmar, Sweden; 2010.

[54] Naturvårdsverket. Remediation of Contaminated Areas. Sweden: Naturvårsverket; 2008.

[55] Berlin J. Environmental Life Cycle Assessment (LCA) of Swedish Semi-Hard Cheese. International Dairy Journal 2002;12(11):939-53.

[56] CPM. SPINE LCI dataset: Diesel Productions. http://cpmdatabase.cpm.chalmers.se (accessed June 2013)

[57] Suèr P, Nilsson-Påledal S, Norrman J. LCA for Site Remediation: A Literature Review. Soil and Sediment Contamination: An International Journal 2004;13(4):415-25.

[58] Toffoletto L, Deschênes L, Samson R. LCA of Ex-Situ Bioremediation of Diesel-Contaminated Soil (11 pp). Int J Life Cycle Assess 2005;10(6):406-16. 
[59] Kurzweil R. The Singularity Is Near: When Humans Transcend Biology. Penguin (Non-Classics); 2006.

[60] Peixoto RS, Vermelho AB, Rosado AS, Peixoto RS, Vermelho AB, Rosado AS. Petroleum-Degrading Enzymes: Bioremediation and New Prospects. Enzyme Research 2011, Article ID:475193..7 pp. doi 10.4061/2011/475193.

[61] Altshuller AP. Lifetimes of Organic Molecules in the Troposphere and Lower Stratosphere. In: Pitts JN Jr., Metcalf RL., Grosjean D. (ed.) Advances in Environmental Science and Technology. New York: John Wiley \& Sons; 1980..p181-219. 